sociologique, démographique et anthropologique (en collaboration avec des Services et organismes spécialisés) sur les populations locales, et de l'autre, un plan d'intensification des échanges des connaissances ainsi acquises avec des organismes de recherche en Afrique et ailleurs.

[Communicated by B. Holas]

\title{
African Studies at the Centro de Estudos Politicos e Sociais, Lisbon
}

The Portuguese Centro de Estudos Políticos e Sociais has recently undertaken a series of studies in Africa, concerned with cultural, economic, and governmental problems. In addition to its recent publications, it has sponsored studies of economic relations between Portugal and the Arab world and an inquiry into anti-colonialism which will be published before the end of 1957 .

In 1956 Professor Silva Cunha made a preliminary inquiry in Angola and Mozambique to plan a study of indigenous associations in Africa, an account of which has now been published. A field team, led by Professor Silva Cunha, assisted by José Maria Gaspar and André Gonçalves Pereira, will carry out investigations over three years from 1957. Professor Jorge Dias has made a field survey for an intensive study of ethnic minorities in the Portuguese African provinces by a field team in which he will be helped by Margot Schmidt Dias and Viegas Guerreiro over the four-year period I957-60. Fr. Ernesto Domingues, S.J. has made a preliminary study of migration in all Portuguese overseas territories on the basis of which a field team, led by Professor José Sampayo d'Orey, assisted by J. Castilho Soares and António Labisa, will carry out investigations which will include all African provinces.

Further information concerning the plans and progress of African studies at the Centro de Estudos Políticos e Sociais may be obtained from its Director, Dr. Adriano Moreira.

\section{Major Laing's Journey to Timbuktu, I825-6}

An article by Miss Maboth Moseley in West Africa (24 August 1957), called 'The Gap in the Shelf', throws new light on the journey made by Major Alexander Gordon Laing to Timbuktu in 1825-6, on the fate of his lost papers, and on the intrigues of Joseph-Louis Rousseau, French Consul-General in Tripoli at the time. Miss Moseley's article and her recently finished book of the same title are based on original documents, many of them unpublished, in the Public Record Office and the Archives of the Royal Society in London and on information from French sources, notably that supplied by Professor Th. Monod, Director of IFAN, Dakar.

\section{Social Study of the Anchau Resettlement Scheme, Northern Nigeria}

Professor H. Miner of the University of Michigan, with the aid of a Rockefeller Foundation grant, is engaged on a nine-month field study of the methods used and results achieved in the Anchau Resettlement Scheme, which was started twenty years ago in Northern Nigeria.

\section{Anthropological Research at the Institute of Social and Economic Research, Rhodes University, South Africa}

ANTHRopological research at the Institute of Social and Economic Research, Rhodes University, is at present mostly co-ordinated into three schemes, under the direction of Professor P. Mayer, for which the field is provided by the Xhosa-speaking peoples of the 